\title{
The seventh SUITMA conference held in Toruń, Poland, September 2013
}

\author{
Jean Louis Morel ${ }^{1} \cdot$ Przemyslaw Charzyński $^{2} \cdot$ Richard K. Shaw $^{3} \cdot$ Ganlin Zhang $^{4}$
}

Received: 11 June 2015 / Accepted: 13 June 2015 / Published online: 9 July 2015

(C) Springer-Verlag Berlin Heidelberg 2015

Keywords IUSS working group $\cdot$ SUITMA $\cdot$ Urban soils

The Working Group (WG) on Soils of Urban, Industrial, Traffic, Mining and Military Areas (SUITMAs) is one of the International Union of Soil Sciences (IUSS) working groups. Established in 1998, it is charged with promoting knowledge about soil cover in areas with strong technological pressures. Technogenic activities have led to the construction of artificial soils, as well as soil sealing or extraction due to mining of materials not affected by surface processes in natural landscapes. Approximately $3 \%$ of the world's land surface is covered with such areas.

In the urban ecosystem, soils play an essential role in terms of their functions and ecosystem services. The abilities of SUITMAs to provide ecosystem services are different from those provided by natural soils, and are often impaired (Lehmann and Stahr 2007; Morel et al. 2015). SUITMAs are more likely to contain toxic substances than other types

Jean Louis Morel

Jean-Louis.Morel@univ-lorraine.fr

1 Laboratoire Sols et Environnement, University of Lorraine, 2, avenue de la Forêt de Haye, 54518 Vandoeuvre-lès-Nancy, France

2 Department of Soil Science and Landscape Management, Faculty of Earth Sciences, Nicolaus Copernicus University, Lwowska St. 1, 87-100 Toruń, Poland

3 USDA-Natural Resources Conservation Service, NRCS-New Jersey, 220 Davidson Ave, 4th Floor, Somerset, NJ 08873, USA

4 Department of Soil Resources and Remote Sensing Application, Institute of Soil Science, Chinese Academy of Sciences, 71 East Beijing Road, 210008 Nanjing, China of soils and should be treated with care (IUSS Working Group WRB 2014). Nevertheless, the benefits of SUITMAs and other urban soils are numerous. Those soils provide the following: groundwater recharge for water supply; a medium for alternative storm-water management; plant products for food supply; sites for recreational activities; and buffering of temperature and humidity. They serve as a medium for retention, decomposition and immobilization of contaminants, and dust entrapment to reduce its content in the air. SUITMAs can also be considered as historical archives (Lehmann and Stahr 2007). Thus, knowledge that SUITMAs are precious should be promoted in society.

Since 2000, a SUITMA conference has taken place every second year. Seven meetings have already been organized: in Essen, Germany, in 2000; Nancy, France, in 2003; Cairo, Egypt, in 2005; Nanjing, China, in 2007; New York City, USA, in 2009; Marrakech, Morocco, in 2011; and in Torun, Poland, in 2013. The 2013 conference held in Torun was coorganized by the Department of Soil Science and Landscape Management of Nicolaus Copernicus University and the Polish Soil Science Society. More than 110 participants attended the event, and a total of 47 oral and 74 posters were presented in six sessions: (1) Classification of SUITMAs; (2) SUITMAs as a resource of goods; (3) Degradation of SUITMAs and human health; (4) SUITMAs and climate change; (5) Biodiversity in SUITMAs; and (6) SUITMAs and culture.

Two books were published especially for the conference, including "Technogenic Soils of Poland" (Charzyński et al. 2013a) and "Technogenic Soils Atlas" (Charzyński et al. 2013b). The papers included in this special issue of Journal of Soils and Sediments reflect some of the more important research directions for the SUITMA WG, including classification and genesis: with Jangorzo et al. (2015) examining the effects of biological activity on pedogenesis; Amossé et al. 
(2015) comparing urban soils with alluvial soils; Greinert (2015) investigating soil heterogeneity in a Polish town; and Charzyński et al. (2015) exploring Edifisols, those soils forming on buildings. There is attention to ecosystem services provided by SUITMAs, including an evaluation system from Morel et al. (2015); a strategy for protection based on land use history by Franck-Néel et al. (2015); and several case studies examining SUITMA performance, such as Coulon et al. (2015) who examine storm water infiltration basin using image analysis; Kulachkova and Mozharova (2015) who investigate filtration fields and greenhouse gases; Lisovitskaya et al. (2015) who examine various types of biofilters in Moscow; and Nehls et al. (2015) who explore nutrient recycling from constructed soils. SUITMAs and human health are still an important topic, as several authors examine different sources of contaminants: Abel et al. (2015) evaluate construction rubble; Findoráková et al. (2015) examine reservoir sediments in Eastern Slovakia; Schwager et al. (2015) investigate green roof materials; Jean-Soro et al. (2015) assess an urban garden in Nantes; and Vácha et al. (2015) compare two coal mining areas in the Czech Republic. A city-wide perspective on contaminant distribution in a Hungarian town is also provided by Horváth et al. (2015); in addition, Łukasik et al. (2015) investigate trace metal assessment via magnetic susceptibility; and Filipović et al. (2015) examine water flow and nitrogen dynamics under a golf course.

During the meeting, Mexico City, United Mexican States, was selected to host the next conference (SUITMA 8, September 20-30, 2015: http://www.geologia.unam.mx/ $\sim$ cisu/suitma8/).

\section{References}

Abel S, Nehls T, Mekiffer B, Wessolek G (2015) Heavy metals and benzo[a]pyrene in soils from construction and demolition rubble. $\mathrm{J}$ Soils Sediments. doi:10.1007/s11368-014-0959-4 (this issue)

Amossé J, Le Bayon R-C, Gobat J-M (2015) Are urban soils similar to natural soils of river valleys? J Soils Sediments. doi:10.1007/ s11368-014-0973-6 (this issue)

Charzyński P, Hulisz P, Bednarek R (eds) (2013a) Technogenic soils of Poland. Polish Society of Soil Science, Torun

Charzyński P, Markiewicz M, Świtoniak M (eds) (2013b) Technogenic soils atlas. Polish Society of Soil Science, Torun

Charzyński P, Hulisz P, Bednarek R, Piernik A, Winkler A, Chmurzyński M (2015) Edifisols - a new soil unit of technogenic soils. J Soils Sediments. doi:10.1007/s11368-014-0983-4 (this issue)

Coulon A, Cannavo P, Charpentier S, Vidal-Beaudet L (2015) Cloggingup of a stormwater infiltration basin: a laboratory approach using image analysis. J Soils Sediments. doi:10.1007/s11368-014-0951-z (this issue)
Filipović V, Toor GS, Ondrašek G, Kodešová R (2015) Modeling water flow and nitrate-nitrogen transport on golf course under turfgrass. J Soils Sediments. doi:10.1007/s11368-014-0980-7 (this issue)

Findoráková L, Šestinová O, Danková Z, Findorák R, Hančulák J (2015) Thermal and spectral characterization of bottom sediment from the water reservoir Ruž ín No. I in Eastern Slovakia and the kinetics of heavy metal cation leaching. J Soils Sediments. doi:10.1007/ s11368-014-0941-1 (this issue)

Franck-Néel C, Borst W, Diome C, Branchu P (2015) Mapping the land use history for protection of soils in urban planning: what reliable scales in time and space? J Soils Sediments. doi:10.1007/s11368014-1017-y (this issue)

Greinert A (2015) The heterogeneity of urban soils in the light of their properties. J Soils Sediments. doi:10.1007/s11368-014-1054-6 (this issue)

Horváth A, Szücs P, Bidló A (2015) Soil condition and pollution in urban soils: evaluation of the soil quality in a Hungarian town. J Soils Sediments. doi:10.1007/s11368-014-0991-4 (this issue)

IUSS Working Group WRB (2014) World Reference Base for Soil Resources 2014. International soil classification system for naming soils and creating legends for soil maps, World Soil Resources Reports, 106, FAO, Rome, Italy

Jangorzo NS, Watteau F, Hajos D, Schwartz C (2015) Nondestructive monitoring of the effect of biological activity on the pedogenesis of a Technosol. J Soils Sediments. doi:10.1007/s11368-014-1008-Z (this issue)

Jean-Soro L, Le Guern C, Bechet B, Lebeau T, Ringeard M-F (2015) Origin of trace elements in an urban garden in Nantes, France. J Soils Sediments. doi:10.1007/s11368-014-0952-y (this issue)

Kulachkova SA, Mozharova NV (2015) Generation, sink, and emission of greenhouse gases by urban soils of reclaimed filtration fields. J Soils Sediments. doi:10.1007/s11368-014-0940-2 (this issue)

Lehmann A, Stahr K (2007) Nature and significance of anthropogenic urban soils. J Soils Sediments 7:247-260

Lisovitskaya O, Lebed-Sharlevich I, Mozharova N, Kulachkova S (2015) Efficiency of methane biotransformation of soil and soil-like biofilters in Moscow. J Soils Sediments. doi:10.1007/s11368-0140965-6 (this issue)

Łukasik A, Szuszkiewicz M, Magiera T (2015) Impact of artifacts on topsoil magnetic susceptibility enhancement in urban parks of the Upper Silesian conurbation datasets. J Soils Sediments. doi:10. 1007/s11368-014-0966-5 (this issue)

Morel J-L, Chenu C, Lorenz K (2015) Ecosystem services provided by soils of urban, industrial, traffic, mining, and military areas (SUITMAs). J Soils Sediments. doi:10.1007/s11368-014-0926-0 (this issue)

Nehls T, Schwartz C, John Kim K-H, Kaupenjohann M, Wessolek G, Morel J-L (2015) Letter to the editors: Phyto-P-mining — secondary urban green recycles phosphorus from soils constructed of urban wastes. J Soils Sediments. doi:10.1007/s11368-014-1023-0 (this issue)

Schwager J, Schaal L, Simonnot M-O, Claverie R, Ruban V, Morel J-L (2015) Emission of trace elements and retention of $\mathrm{Cu}$ and $\mathrm{Zn}$ by mineral and organic materials used in green roofs. J Soils Sediments. doi:10.1007/s11368-014-0962-9 (this issue)

Vácha R, Skála J, Čechmánková J, Horváthová V, Hladík J (2015) Toxic elements and persistent organic pollutants derived from industrial emissions in agricultural soils of the Northern Czech Republic. J Soils Sediments. doi:10.1007/s11368-015-1120-8 (this issue) 